\section{A Hundred Years of Chemistry}

By Prof. Alexander Findlay. (100 Years Series.) Second edition. Pp. 318. (London: Gerald Duckworth and Co., Ltd., 1948.) 2ls. net.

THE numerous admirers of Prof. Alexander Findlay's writings will welcome this new and revised edition of a remarkably interesting and useful book. His masterly review of a century of effort and achievement in the constantly widening domain of chemistry constitutes a great tribute to the author's power of taking a comprehensive view of a subject of bewildering complexity and expressing it in a way as attractive as informative. The book offers something to all who have an interest in chemistry; its character is such that it will be equally a.t home on the chemist's favourite bookshelf or in the lending or reference section of a library.

The new edition takes cognizance of the outstanding advances that chemistry has made in the last ten years, notably in the fields of atomic constitution, artificial transmutation of elements, nutrition, and medicinal specifics. During this fateful period, as the author remarks, "we have been the witnesses of one of the greatest achievements of the human mind, the utilization of atomic or nuclear energy. That this great achievement should have found its first use in human and material destruction by an atom-bomb is one of those tragedies which are a constant challenge to man's moral nature but which do not diminish the greatness of the achievement or make more difficult the application of man's knowledge to beneficent ends." In this work Prof. Findlay maintains his high reputation for accuracy; the only error of any note that has caught the eye of one with a peculiar interest in the immediate subject is the usurpation of hydrogen by hydroxyl in the molecule of chloroiodomethanesulphonic acid (p. 65).

The numerous footnotes illuminate in a striking way the writer's painstaking care and industry in going to original sources for his detailed information. The thumb-nail sketches of celebrated chemists given at the end of the book under the heading of "bio. graphical notes" are very apt and replete with the concise facts so often needed and so hard to find.

JOHN READ

Historical Geology

The Geologic History of North America. By Prof. Russell C. Hussey. Second edition. Pp. xi+465. (New York and London: McGraw-Hill Book Co., Inc., 1947.) $19 s$.

7 HIS account of the geological history of North

America is intended for students and readers interested in the cultural aspect of the science. The author, like all geologists, believes that a knowledge of the major events in the history of the earth should be part of a liberal education. Since a new edition has been called for only three years after the first publication of the book, it appears that he has attracted the public he desires and deserves. This revised edition has been simplified by removal of some material (an all too rare operation in the preparation of new editions) and has been brought up to date, and better illustrations have been given where possible.

The arrangement follows that of the first edition. First are presented the general principles of historical geology, the organisation of the geological record, the nature and significance of fossils and the main concepts of evolution. Special aspects of these general principles are developed in the account of the geological history of North America which follows. For example, the causes of marine transgressions are discussed with the Cambrian, the habitats of marine animals with the Ordovician, coral reefs with the Silurian and so on. For each geological period, the lands and seas and their sediments, the climate, crustal disturbances and life are dealt with in this order so that the story keeps moving. Emphasis throughout is placed on the development of life in this story, and this emphasis is increased as we approach modem times. The account of Tertiary life includes the geological history of the horses, elephants and other mammals, and the last chapter, one of more than thirty pages, deals with that of man. The illustrations, many from the great American museums, are abundant and mainly excellent. In spite of its sub-title, this book will be of service outside the United States as well as within, for it presents the broad essential principles by which the history of the earth's crust everywhere should be read.

\section{The Mineral Key}

By Howard B. Graves, Jr. Pp. viii+178. (New York and London: MeGraw-Hill Book Co., Inc., 1947.) $20 s$.

MOST of this small book consists of mineral 1 identification tables which are preceded by introductory chapters on equipment and chemicals needed and methods of identification. The determ. inative tables list some six hundred minerals, classified primarily according to colour, streak, cleavage and presence or absence of water, but optical properties and specific gravity are not included. Isomorphous series are each shown under one species, and varieties are omitted: amethyst and agate are, for example, excluded although many rare minerals are listed. The tables will be useful to experienced mineralogists, more particularly for determining opaque minerals; but in a book intended for amateurs more emphasis should, perhaps, have been placed on the caution necessary in identifying minerals with certainty. The price seems rather high for a book of this format.

P. A. S.

\section{Insect Pests of Glasshouse Crops}

By Prof. Herbert W. Miles and Mary Miles. Second edition, revised. Pp. $200+24$ plates. (London : Crosby Lockwood and Son, Ltd., 1948.) 15s. net.

A SURPRISINGLY large number of species of $A$ insects and related small animals occur in glasshouses and cause injury to the plants that are grown therein. A perusal of the present handbook will convince the reader on this point : at the same time it will enable him (or her) to recognize any of these creatures that he is likely to come across. The grower, whether he has only a conservatory or farms an acre or more of glasshouses, will find just the sort of information that he needs and what control measures are best suited for any particular enemy of his plants. The first edition of the book appeared in 1935 , and the present issue is a revised version with some modification as regards the presentation of the text and the addition of several new illustrations. Since the book no longer has pages of trade advertisements incorporated, the increase of price from $8 s$. $6 d$. to $15 s$. is reasonable under present-day conditions. Well printed and illustrated, and with a good index, it is indeed excellent value for the price. 